\title{
Condyloma-like squamous cell carcinoma of the vulva: report of two midline cases
}

This article was published in the following Dove Press journal:

Clinical, Cosmetic and Investigational Dermatology

7 September 2012

Number of times this article has been viewed

\author{
Shyam B Verma' \\ Uwe Wollina ${ }^{2}$ \\ 'Nirvana Clinic, Vadodara, \\ Gujarat, India; ${ }^{2}$ Department of \\ Dermatology and Allergology, \\ Academic Teaching Hospital \\ Dresden-Friedrichstadt, \\ Dresden, Germany
}

Correspondence: Uwe Wollina Department of Dermatology and Allergology, Academic Teaching Hospital Dresden-Friedrichstadt, Friedrichstrasse 4I, 01067 Dresden, Germany Emailwollina-uw@khdf.de

\begin{abstract}
Vulvar cancer is uncommon and may be confused with genital condylomata. We report two cases of middle-aged women presenting with exophytic vulvar tumors of the midline for which diagnosis of a vulvar squamous cell carcinoma was confirmed by histopathology. Risk factors, staging, and treatment options are discussed.
\end{abstract}

Keywords: condyloma, human papillomavirus (HPV), squamous cell carcinoma, surgery, vulva

\section{Introduction}

Vulvar carcinomas are rare malignancies, and squamous cell carcinoma (SCC) of the vulva account for about $80 \%$ of such cases. ${ }^{1}$ Vulvar intraepithelial neoplasia and vulvar Bowen's disease are considered as possible precursors of vulvar SCC. ${ }^{2}$

There are two major ways vulvar SCC can develop: (a) 8.6\%-40\% of cases emerge due to infection with carcinogenic subtypes of human papilloma virus (HPV) and (b) $60 \%-70 \%$ of tumors are not related to HPV. ${ }^{3-5}$ Among HPV types, HPV-16 seems to be the most commonly isolated in vulvar carcinomas with HPV-11 and HPV-6 being less common. ${ }^{4}$ Vulvar SCC with a warty surface has been strongly linked with HPV-33, HPV-45, HPV-52, HPV-18, and HPV-16. ${ }^{6}$

Several conditions of either autoimmune or infectious origin and miscellaneous disorders have been associated with development of vulvar SCC, such as Hailey-Hailey disease, ${ }^{7}$ pemphigus vulgaris and systemic lupus erythematosus, ${ }^{8}$ lichen sclerosus and Langerhans cell histiocytosis, ${ }^{9}$ Crohn's disease, ${ }^{10}$ Fanconi's anemia, ${ }^{11}$ and infection with human immunodeficiency virus (HIV). ${ }^{12}$

In women aged less than 40 years, vulvar SCC is extremely rare. ${ }^{13}$ The availability of HPV vaccination may lead to a reduction in HPV-associated vulvar SCC. ${ }^{4} \mathrm{SCC}$ is an important clinical and histological differential diagnosis in anogenital condylomata accuminata. ${ }^{14}$ However, SCC may be misdiagnosed as condyloma. We report two middle-aged females presenting with condyloma-like vulvar midline SSC.

\section{Case reports Case I}

A 41-year-old woman was seen in consultation for the combination of an asymptomatic hyperpigmented plaque type vulvar lesion on the right side and a painful exophytic nodule of the contralateral site arising from a larger flat leucoplakic lesion (Figure 1). The lesions were noted for $>1$ year (plaque) and 3 months (nodule). She was obese and was on treatment for insulin-dependent diabetes mellitus. 


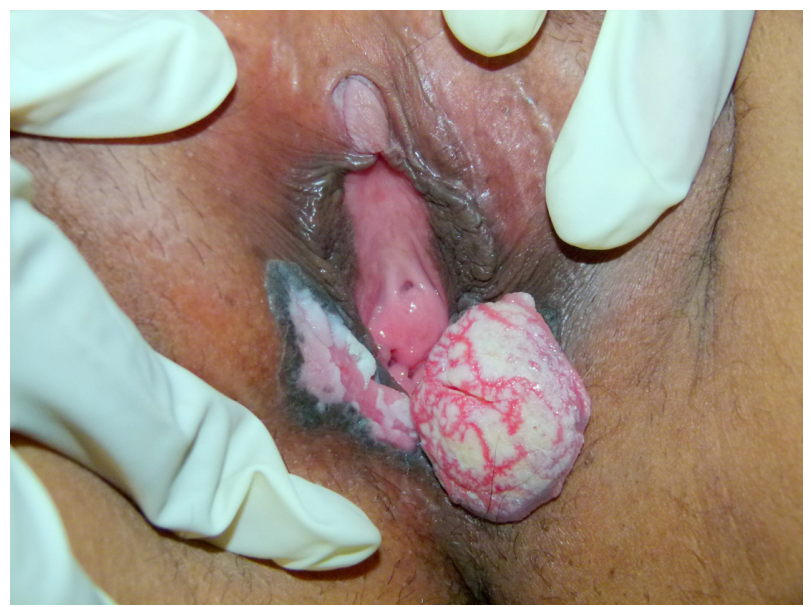

Figure I Warty exophytic SCC of the vulva (case I).

Abbreviation: SCC, squamous cell carcinoma.

The hyperpigmented lesion was flat, macular, and had well-defined borders. The nodule on the left side of the vulva was about $4 \mathrm{~cm}$ in diameter, was pedunculated, had a firm consistency, was covered in whitish film-like material and exhibited a verrucous whitish cover. Two diagnostic biopsies were taken from each side. Histopathological examination of the nodule revealed an epithelial proliferation with the formation of horn pearls, keratinocytes with nuclear polymorphism, and increased mitotic activity (Figure 2). The basement membrane was not well-maintained but deeper infiltration was absent. The diagnosis was squamous cell carcinoma, Broder grade II. The other lesion was diagnosed as pigmented Bowen's disease with pagetoid growth of enlarged intraepithelial keratinocytes developing into SCC. The tumor was staged as stage II according to International Federation of Gynecology and Obstetrics staging guidelines and T2N0M0 according to Union for International Cancer Control guidelines (Table 1). ${ }^{15}$ The patient was referred to the gynecologist for vulvectomy.

\section{Case 2}

A 44-year-old female presented with asymptomatic condyloma-like protrusions affecting labia majora and perineum and she noted $>2$ years of slow enlargement (Figure 3). She was a smoker for $>20$ package-years but her medical history was unremarkable. The tumor presented as firm mass infiltrating the deeper structures. Magnetic resonance imaging revealed a deep subcutaneous neoplasia, extruding vagina and anus, and penetrating urogenital diaphragm including the musculus peroneus profundus measuring $33 \times 43 \times 42 \mathrm{~mm}$. Lymph node metastasis was observed in the right groin. Histopathology revealed SSC, Broder grade III.
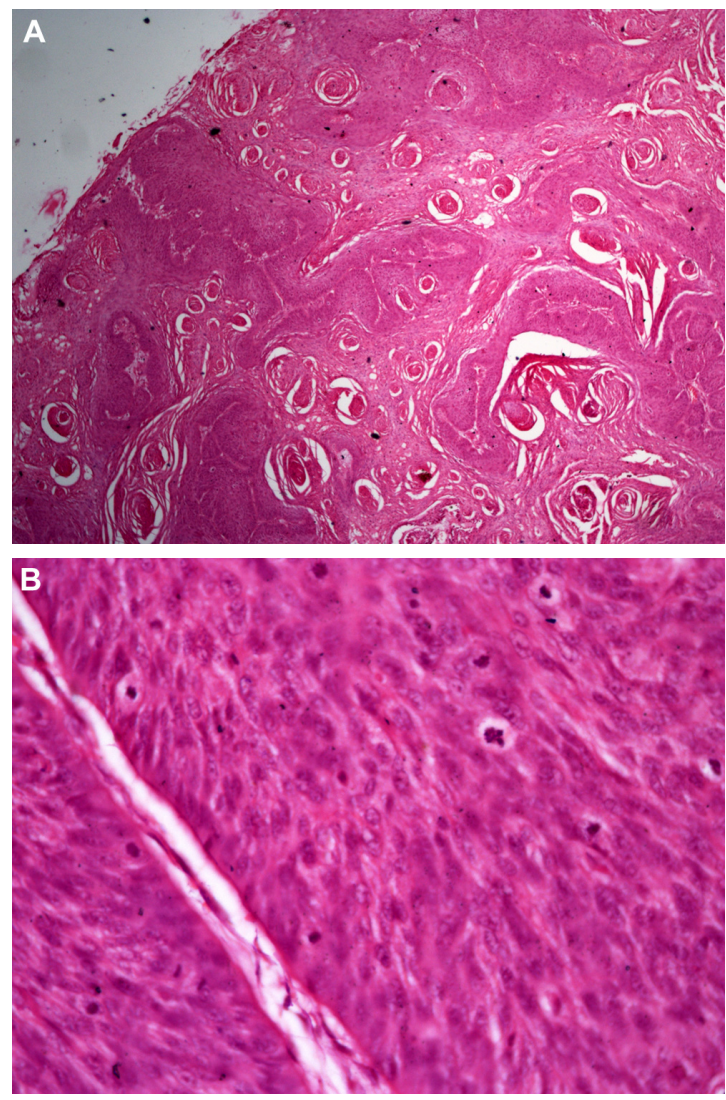

Figure 2 Histopathology of the vulvar squamous cell carcinoma (case 1): (A) Overview with epitheloid strands, cellular and nuclear atypias and formation of horn pearls $(\times 4)$. (B) Multiple mitoses $(\times 40)$. Hematoxylin-eosin stains.

The tumor was staged as stage IIIA according to International Federation of Gynecology and Obstetrics staging guidelines and T3N1M0 according to Union for International Cancer Control guidelines (Table 1). ${ }^{15}$ Surgery was performed for

Table I Revised FIGO classification of vulvar carcinoma ${ }^{15}$

IA Tumor confined to the vulva or perineum, $\leq 2 \mathrm{~cm}$ in size with stromal invasion $\leq \mathrm{I} \mathrm{mm}$, negative nodes

IB Tumor confined to the vulva or perineum, $>2 \mathrm{~cm}$ in size or with stromal invasion $>1 \mathrm{~mm}$, negative nodes

II Tumor of any size with adjacent spread (I/3 lower urethra, I/3 lower vagina, anus), negative nodes

IIIA Tumor of any size with positive inguinofemoral lymph nodes (i) I lymph node metastasis greater than or equal to $5 \mathrm{~mm}$

(ii) I-2 lymph node metastasis(es) of less than $5 \mathrm{~mm}$

IIIB (i) 2 or more lymph nodes metastases greater than or equal to $5 \mathrm{~mm}$ (ii) 3 or more lymph nodes metastases less than $5 \mathrm{~mm}$

IIIC Positive node(s) with extracapsular spread

IVA (i) Tumor invades other regional structures (2/3 upper urethra, 2/3 upper vagina), bladder mucosa, rectal mucosa, or fixed to pelvic bone

(ii) Fixed or ulcerated inguinofemoral lymph nodes

IVB Any distant metastasis including pelvic lymph nodes

Abbreviation: Reproduced, with permission granted by the International Federation of Gynecology and Obstetrics (FIGO), from:Pecorelli, S. Revised FIGO staging for carcinoma of the vulva, cervix, and endometrium. Int J Gynecol Obstet 2009;105(2): 103-104. 


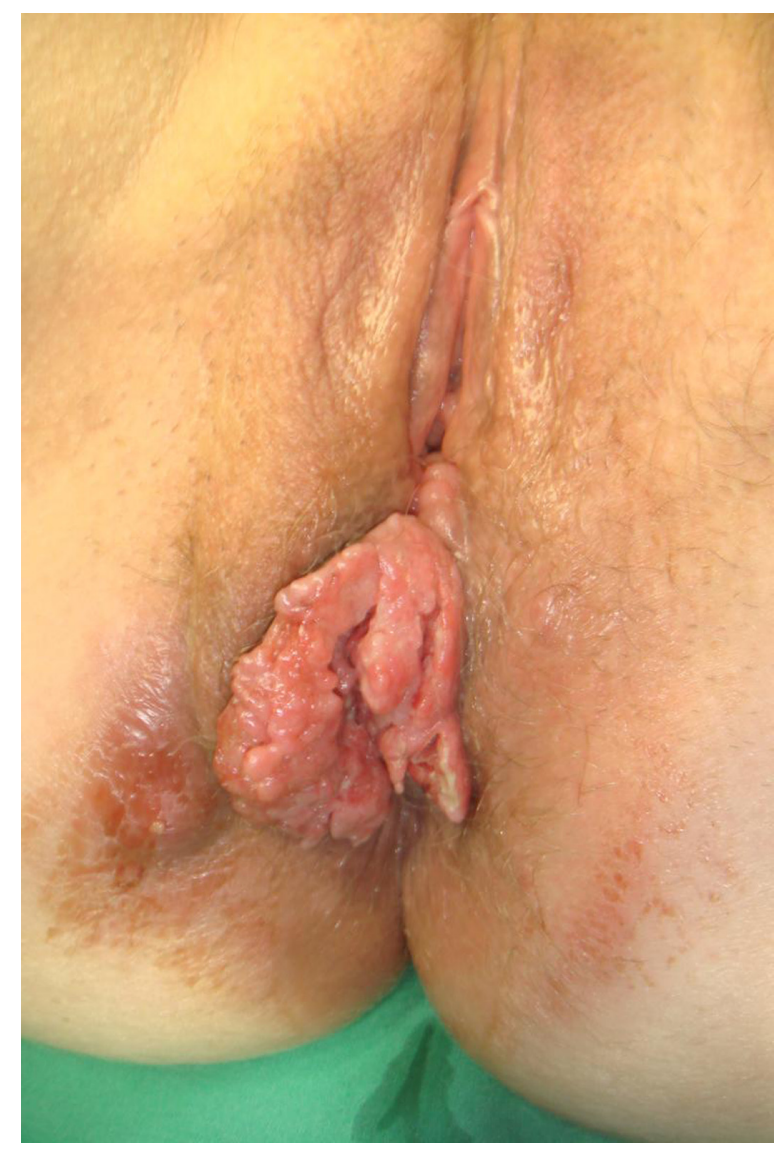

Figure 3 Condyloma-like exophytic growth of vulvar squamous cell carcinoma (case 2).

tumor debulking (Figure 4). The patient was referred to the gynecologist for combined chemoradiotherapy.

\section{Discussion}

Vulvar cancer can be differentiated as two types: type 1 is seen in patients younger than 65 years old with frequent detection of HPV DNA and a strong association to preexisting condyloma, vulvar intraepithelial neoplasia, sexually

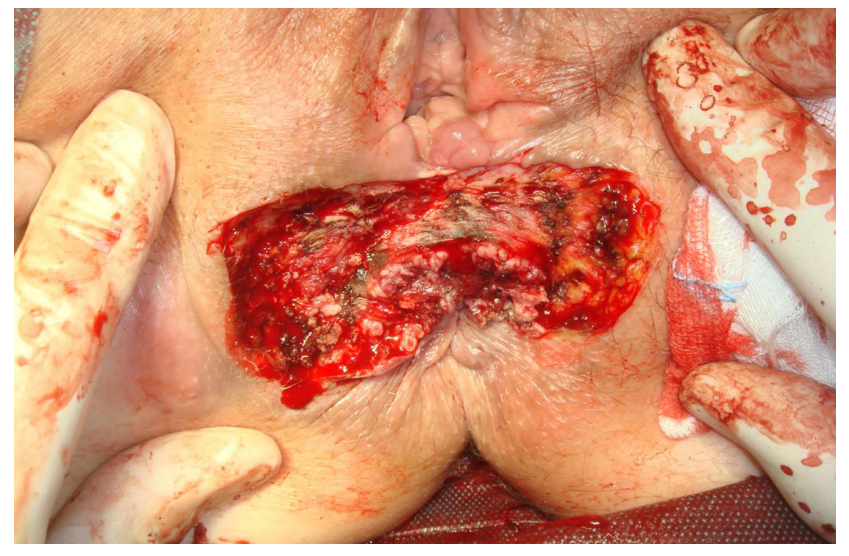

Figure 4 Operation situs after debulking surgery (case 2). transmitted diseases, and cigarette smoking. Type 2 affects elderly women. SCC is seen more often in type 2 vulvar cancer. ${ }^{16}$ Our patients, however, belonged to the age-group of type 1 and both had SCC Broder grades II and III.

Vulvar SCC may be completely asymptomatic. When symptoms are present, the most common include pruritus vulvae, vulvar bleeding or pain, swelling, or vaginal discharge. ${ }^{16,17}$ Often, the patient does not complain due to cultural reasons, the so-called "culture of silence", due to embarrassment, or for economic reasons. Vulvar SCC may be confused with condyloma ${ }^{14}$ and therefore may be inadequately treated by various modalities. Important differential diagnoses of vulvar SCC are listed in Table 2.

Table 2 Differential diagnoses of vulvar SCC

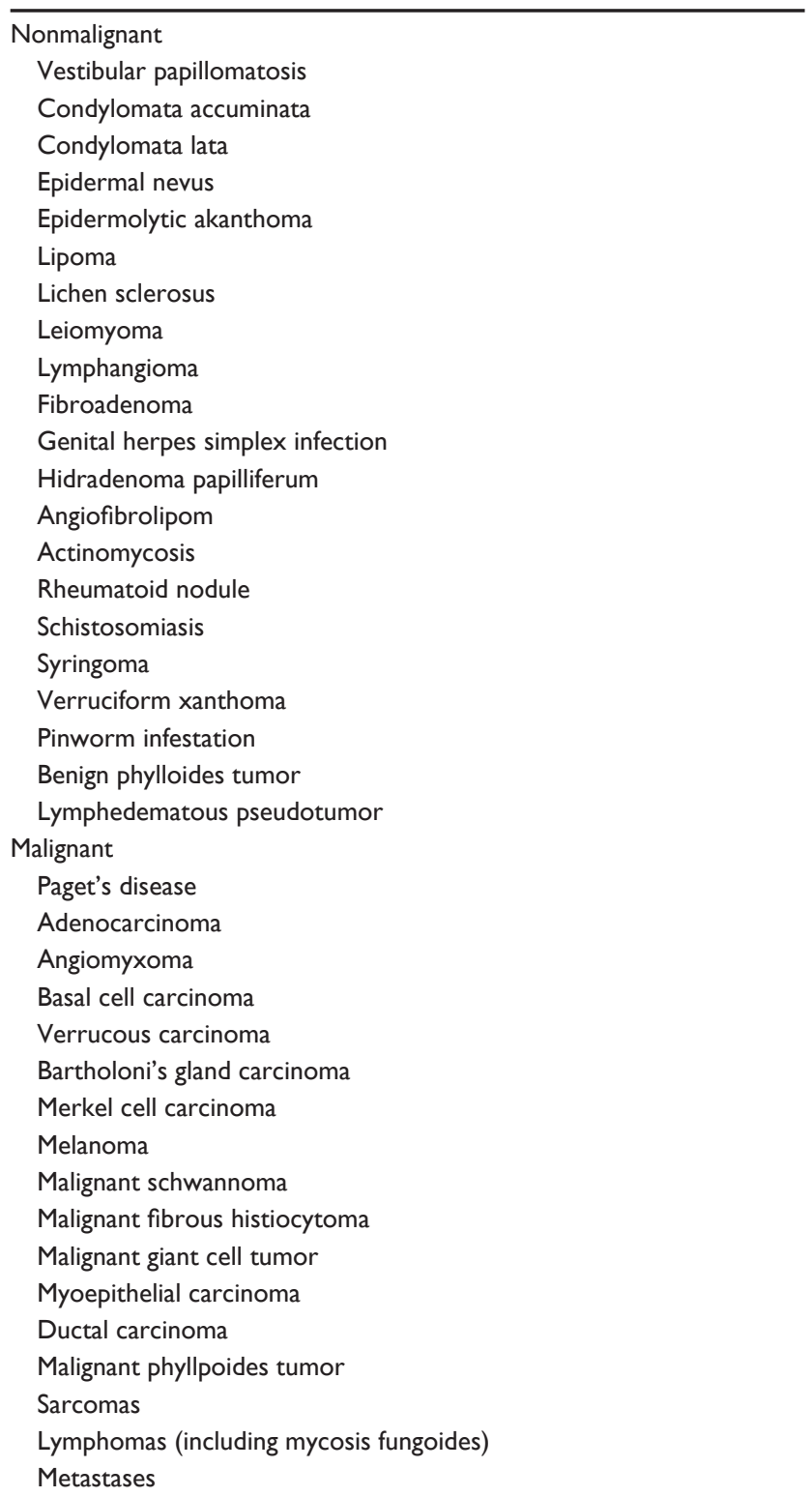

Abbreviation: SCC, squamous cell carcinoma. 
The 5-year survival rates for vulvar SCC have been estimated as $41 \%$ for India, ${ }^{18} 68 \%$ for South Korea, ${ }^{19}$ and $86 \%$ in the United States. ${ }^{1}$ The most important negative prognostic factor for vulvar SCC is the inguinofemoral lymph node status at the time of initial diagnosis. ${ }^{20}$ Surgery remains the cornerstone of therapy. Individualized vulvectomy should be accompanied by groin lymph node dissection for tumors with a diameter of at least $2 \mathrm{~cm}$ and those invading $1 \mathrm{~mm}$ or deeper. Medially located tumors may spread bilaterally. ${ }^{21,22}$ Surgery, tumor stage, and stromal invasion of less than $9 \mathrm{~mm}$ were the most dominant predictors for relapse-free survival in a recent study in Italy. ${ }^{23}$ The distance of the surgical margins is critical for the prevention of local relapses. In a study analyzing 93 patients with vulvar carcinoma, a margin of more than $8 \mathrm{~mm}$ did not improve recurrence rate. ${ }^{24}$ In advanced cases, neoadjuvant chemotherapy is a beneficial option if surgery can be performed thereafter. ${ }^{25}$ The combination of chemotherapy and radiation is an option for patients where surgery is impossible. ${ }^{26,27}$ In our cases, vulvectomy is planned for case 1 and combined chemoradiotherapy after debulking surgery is planned for case 2 .

In conclusion, it is important for dermatologists to be aware of vulvar SCC and consider this malignancy when dealing with large vulvar condylomas. Early recognition with reference to treatment by gynecologists, oncologists, and radiologists helps to improve outcome.

\section{Disclosure}

The authors report no conflicts of interest in this work.

\section{References}

1. Saraiya M, Watson M, Wu X, et al. Incidence of in situ and invasive vulvar cancer in the US, 1998-2003. Cancer. 2008;113(Suppl 10): 2865-2872.

2. Nakanishi G, Fujii K, Asagoe K, Tanaka T, Iwatsuki K. Human papillomavirus genome integration in multifocal vulvar Bowen's disease and squamous cell carcinoma. Clin Exp Dermatol. 2009;34(8): e965-e967.

3. Akerman G, Dussour C, Haddad B, Paniel BJ, Rouzier R. Epidemiology of vulvar intra-epithelial neoplasias [French]. Gynecol Obstet Fertil. 2007;35(12):1251-1256.

4. Garland SM, Insinga RP, Sings HL, Haupt RM, Joura EA. Human pappilomavirus infections and vulvar disease development. Cancer Epidemiol Biomarkers Prev. 2009;18(6):1777-1784.

5. Kowalewska M, Szkoda MT, Radziszewski J, Ptaszynski K, Bidzinski M, Siedlecki JA. The frequency of human papillomavirus infection in polish patients with vulvar squamous cell carcinoma. Int J Gynecol Cancer. 2010;20(3):434-437.

6. Sutton BC, Allen RA, Moore WE, Dunn ST. Distribution of human papillomavirus genotypes in invasive squamous carcinoma of the vulva. Mod Pathol. 2008;21(1):345-354.

7. von Felbert V, Hampl M, Talhari C, Engers R, Megahed M. Squamous cell carcinoma arising from a localized vulval lesion of Hailey-Hailey disease after tacrolimus therapy. Am J Obstet Gynecol. 2010;203(3): e5-e7.
8. Bifulco G, Mandato VD, Piccoli R, et al. Early invasive vulvar squamous cell carcinoma arising in a women with vulvar pemphigus vulgaris and systemic lupus erythematosus. BMC Cancer. 2010;10:324.

9. Simons M, Van De Nieuwenhof HP, Van der Avoort IA, Bulten J, De Hullu JA. A patient with lichen sclerosus, Langerhans cell histiocytosis, and invasive squamous cell carcinoma of the vulva. Am J Obstet Gynecol. 2010;203(2):e7-e10.

10. Kesterson JP, South S, Lele S. Squamous cell carcinoma of the vulva in a young woman with Crohn's disease. Eur J Gynaecol Oncol. 2008;29(6): $651-652$.

11. Mousavi A, Abbasi F, Abadi AG, Hashemi FA. Vulvar squamous cell carcinoma associated with Fanconi's anemia. Int J Hematol. 2010;91(3): 498-500.

12. Silverberg MJ, Chao C, Leyden WA, et al. HIV infection and the risk of cancers with and without a known infectious cause. AIDS. 2009; 23(17):2337-2345.

13. Keskin N, Iyibozkurt AC, Topuz S, SalihoĞlu Y, Bengisu E, Berkman S. Invasive squamous carcinoma of the vulva in women aged less than 40 years: report of two cases and a third case diagnosed during pregnancy. Eur J Gynaecol Oncol. 2008;29(4):399-401.

14. Bambao C, Nofech-Mozes S, Shier M. Giant condyloma versus verrucous carcinoma: a case report. J Low Genit Tract Dis. 2010;14(3): 230-233.

15. Pecorelli S. Revised FIGO staging for carcinoma of the vulva, cervix, and endometrium. Int J Gynaecol Obstet. 2009;105(2):103-104.

16. Canavan TP, Cohen D. Vulvar cancer. Am Fam Physician. 2002;66(7): 1269-1274.

17. Eke AC, Alabi-Isama LI, Akabuilke JC. Management options for vulvar carcinoma in a low resource setting. World J Surg Oncol. 2010; 8:94.

18. Sharma DN, Rath GK, Kumar S, Bhatla N, Julka PK, Sahai P. Treatment outcome of patients with carcinoma of vulva: experience from a tertiary cancer center of India. J Cancer Res Ther. 2010;6(4): 503-507.

19. Kim MK, Kim JW, Lee JM, et al. Validation of a nomogram for predicting outcome of vulvar cancer patients, primarily treated by surgery, in Korean population: multicenter retrospective study through Korean Gynecologic Oncology Group (KGOG-1010). J Gynecol Oncol. 2008;19(3):191-194.

20. Woelber L, Mahner S, Voelker K, et al. Clinicopathological prognostic factors and patterns of recurrence in vulvar cancer. Anticancer Res. 2009;29(2):545-552.

21. ScheistrØen M, Nesland JM, Tropé C. Have patients with early squamous carcinoma of the vulva been overtreated in the past? The Norwegian experience 1977-1991. Eur J Gynecol Oncol. 2002;23(2): 93-100.

22. Ansink A, van der Velden J. Surgical interventions for early squamous cell carcinoma of the vulva. Cochrane Database Syst Rev. 2000;2: CD002036.

23. Nicoletto MO, Parenti A, DelBianco P, et al. Vulvar cancer: prognostic factors. Anticancer Res. 2010;30(6):2311-2317.

24. Groenen SM, Timmers PJ, Burger CW. Recurrence rate in vulvar carcinoma in relation to pathological margin distance. Int J Gynecol Cancer. 2010;20(5):869-873.

25. van Doorn HC, Ansink A, Verhaar-Langereis M, Stalpers L. Neoadjuvant chemoradiation for advanced primary vulvar cancer. Cochrane Database Syst Rev. 2006;3:CD003752.

26. Moore DH. Chemotherapy and radiation therapy in the treatment of squamous cell carcinoma of the vulva: Are two better than one? Gynecol Oncol. 2009;113(3):379-383.

27. Tans L, Ansink AC, van Rooij PH, Kleijnen C, Mens JW. The role of chemo-radiotherapy in the management of locally advanced carcinoma of the vulva: single institutional experience and review of literature. $\mathrm{Am}$ J Clin Oncol. 2011;34(1):22-26. 


\section{Publish your work in this journal}

Clinical, Cosmetic and Investigational Dermatology is an international, peer-reviewed, open access, online journal that focuses on the latest clinical and experimental research in all aspects of skin disease and cosmetic interventions. All areas of dermatology will be covered; contributions will be welcomed from all clinicians and basic science researchers globally. This journal is indexed on CAS. The manuscript management system is completely online and includes a very quick and fair peer-review system, which is all easy to use. Visit http://www.dovepress.com/testimonials.php to read real quotes from published authors. 